\title{
The Influence Of Socio-Scientific Issues On Reflective Judgment Of High School's Student In Ecosystem Material
}

\author{
Na'afi Aisya, Yuni Wibowo, Tien Aminatun \\ Program Studi Pendidikan Biologi, Pascasarjana, Universitas Negeri Malang \\ Jalan Semarang No.5, Sumbersari, Kecamatan Lowokwaru, Malang, Jawa Timur, 65I45, Indonesia \\ surat elektronik: aisyanaafi@gmail.com
}

\begin{abstract}
ABSTRAK
This research is aimed to (I) determined the effect of learning strategy Socio-scientific Issues on students' reflective judgment. This research was a quasi-experimental design with pre-test experimental post-test control group. The variables of research consists of independent variable implementation strategy Socioscientific Issues, the dependent variable was reflective judgment student's ability. The sampling technique used purposive random sampling. The validity of the research instrument used content validity, construct and empirically validity. Test reliability was calculated used Cronbach's Alpha $R_{I I}=0.706$. Analysis of the data used the Wilcoxon test for reflective judgment. The research result showed a significant difference of concept understanding and reflective judgment between experimental class and control class with a significance level of 0.000. Thus, it can be concluded that the application of learning strategies Socioscientific Issues effected on the reflective judgment student on the ecosystem (hydrological cycle) material.
\end{abstract}

Keywords: socio-scientific issues strategies, reflective judgment, ecosystem (hydrological cycle)

\section{Pendahuluan}

Tuntutan pembelajaran sains pada Abad 2I menurut National Science Teachers Association (2006) yaitu untuk menyiapkan siswa dengan berbagai keterampilan dan kecakapan seperti berpikir kritis, kreatif, inovatif, pemecahan masalah, komunikasi, kolaborasi, ICT Literacy dan kepemimpinan. Hal tersebut menuntut kualitas dan keterampilan mumpuni siswa dari tiga segi yaitu segi teknologi informasi, segi keterampilan berpikir tingkat tinggi (higher order thinking skills), dan segi kehidupan atau karir sosial yaitu memiliki nilai, sikap dalam membuat sebuah keputusan.

Sains (biologi) sebagai cabang ilmu pengetahuan yang mempelajari makhluk hidup, lingkungan dan interaksi di dalamnya berkaitan erat dengan fenomena kehidupan sehari-hari yang menuntut pemahaman dan keaktifan siswa dalam membangun pengetahuan baru dari pengalaman dan pengetahuan yang telah dimiliki sebelumnya. Namun, dalam penerapannya hal tersebut belum tercapai secara optimal. Hasil survei Trend International Mathematics Science (TIMSS) Tahun 2007 menyebutkan hanya 5\% siswa Indonesia yang dapat mengerjakan soal kategori tinggi dan advance (memerlukan reasoning), dalam perspektif lain, 78\% siswa Indonesia hanya dapat mengerjakan soal kategori rendah (hanya memerlukan knowing atau hafalan). Data tersebut menunjukkan kemampuan reasoning siswa Indonesia yang masih cenderung rendah.

Cottrell (2005: 4) menjelaskan keterampilan berpikir kritis merupakan keterampilan berpikir tingkat tinggi yang penting untuk dikembangkan bagi diri seseorang karena membuat seseorang lebih akurat dalam memecahkan masalah, memunculkan gagasan baru, memilih yang terbaik dan memodifikasi gagasan tersebut. Hal tersebut didukung oleh Anderson dan Krathwohl (2010: 127) yang menjelaskan berpikir kritis akan membuat seseorang berpikir terbuka dalam mencari kebenaran terhadap suatu permasalahan dan bersikap toleran terhadap ide-ide baru, selain itu dapat menganalisis masalah dengan baik, berpikir secara sistematis, dan dapat memberi keputusan berdasarkan ciri/data yang telah diperoleh.

Berdasarkan pengalaman di lapangan, pembelajaran biologi sudah mengarah pada penggalian informasi terkini melalui buku maupun media massa cetak dan online, namun strategi pembelajaran yang digunakan kurang interaktif sehingga siswa masih cenderung diam. Guru memberikan informasi sebanyak-banyaknya dengan metode direct instruction sehingga siswa tidak memiliki pengalaman dalam memecahkan suatu fenomena/isu yang ditemui pada kehidupan sehari-hari, sehingga siswa kurang mampu merumuskan dan menganalisis keputusan ilmiah berdasarkan pemahaman konsep yang sudah dimiliki sesuai dengan permasalahan yang ditemukan. Sebagian besar siswa kurang dapat 
menghubungkan antara apa yang mereka pelajari dan bagaimana pengetahuan tersebut diaplikasikan pada situasi yang baru.

Penghujung tahun 2013, media massa lokal marak memberitakan pesatnya pembangunan hotel maupun mall di wilayah kota Yogyakarta. Fenomena ini memiliki potensi pembelajaran yang dapat dikembangkan sejalan dengan materi ekosistem khususnya siklus hidrologi. Banyaknya pembangunan hotel menyebabkan luasnya penutupan tanah oleh material tidak tembus air dapat berakibat pada terganggunya proses penyerapan pada siklus hidrologi. Hal ini menarik perhatian berbagai sektor dengan kepentingan yang berbeda-beda, sebagai contoh, sektor pariwisata dengan keuntungan ekonomi dan sektor lingkungan yang terdiri dari kelompok masyarakat merasa resah karena berkurangnya ruang terbuka hijau akibat banyaknya pembangunan gedunggedung. Permasalahan tersebut tidak dapat dilepaskan dari segi ekonomi maupun sosial masyarakat sekitar oleh karena itulah pertimbangan dalam menganalisis suatu permasalahan/isu terkait dibutuhkan kemampuan analisis reflective judgment secara arif dengan melihat segi moral, sosial, ekonomi dan sains dengan modal pemahaman konsep pada permasalahan tertentu.

Isu/fenomena ini berpotensi sebagai kajian siswa dalam upaya menerapkan pengetahuannya dan mengambil keputusan yang tepat berdasarkan pada pemahaman yang telah dimiliki sebelumnya. Aspek kontekstualitas sangat diperlukan dalam pembelajaran biologi mengingat hal tersebut berkaitan dalam kehidupan sehari-hari bukan sekedar melibatkan pengetahuan saja, namun juga memerlukan sikap dan keterampilan menyikapi dan menyelesaikan masalah, sehingga perlu strategi pembelajaran yang beracuan pada aspek kontekstualitas mendukung pembentukan pengetahuan, nilai, sikap, serta keterampilan siswa dalam mengambil keputusan dalam menghadapi suatu isu. Strategi pembelajaran yang potensial untuk diterapkan adalah Socio-scientific Issues based Learning.

Strategi pembelajaran Socio-scientific Issues atau yang dikenal dengan SSI berpotensi untuk mendukung pengembangan kemampuan intelektual, kemampuan berkomunikasi, sikap sosial, kepedulian dan partisipasi siswa. Socio-scientific Issues based Learning (SSI) adalah strategi yang bertujuan untuk menstimulasi perkembangan intelektual, moral dan etika serta kesadaran perihal hubungan antara sains dengan kehidupan sosial (Zeidler, et.al., 2005: 359). Adapun sintaks pembelajaran SSI meliputi delapan tahapan yaitu I). orientasi isu, 2). mengkaji materi, 3). eksplorasi nilaietika secara personal, 4). diskusi kelompok, 5). kontruksi pernyataan kelompok, 6). kajian etik/moral, 7). pengambilan keputusan etis, 8). refleksi/evaluasi. SSI merepresentasikan isu maupun persoalan dalam kehidupan sosial yang berkaitan erat dengan sains. Menurut Sadler (Agung Wijaya, 2013: 42), SSI merujuk pada persoalan sosial yang dilematis berkaitan dengan sains secara konseptual, prosedural maupun teknologi. Penelitian sebelumnya oleh Agung Wijaya (2013), "Pembelajaran Materi Ekosistem dengan Socioscientific Issues dan Pengaruhnya terhadap Reflective Judgment Siswa" menunjukkan potensi SSI untuk memenuhi kebutuhan kontekstualitas pembelajaran serta kecenderungan pengaruh positif pembelajaran SSI terhadap hasil belajar dan munculnya kemampuan reflective judgment yang merata pada diri siswa. Strategi ini memungkinkan metode pembelajaran lain untuk mendukung eksplorasi nilai etik sosial secara personal dan kelompok, oleh karena itu peneliti memadukan metode roleplaying pada penerapan strategi SSI. Hal ini dimaksudkan untuk menguatkan kajian etik setiap siswa terhadap peran yang dimainkannya sehingga unsur konstekstual dilematis setiap unsur sosial dapat terwakilkan.

Implementasi pada materi ekosistem submateri siklus hidrologi diharapkan siswa dapat mengembangkan kemampuan pemahaman konsep yang berimbas pada kemampuan reflective judgment, tidak hanya untuk ketercapaian tujuan pembelajaran tetapi juga sebagai proses pembelajaran reflektif yang dapat mendorong siswa secara sadar memutuskan pertimbangan atas sebuah isu dan memahami pentingnya menjaga lingkungan sekitar.

\section{Metode Penelitian}

Penelitian ini merupakan penelitian kuasi eksperimen dengan desain non-equivalent pre-test post-test control group design.

\begin{tabular}{lccc}
\hline \multicolumn{1}{c}{ Group } & Pre-test & Treatment & Post-test \\
\hline Eksperimen & $\mathrm{Y}_{\mathrm{I}}$ & $\mathrm{X}_{\mathrm{I}}$ & $\mathrm{Y}_{2}$ \\
Kontrol & $\mathrm{Y}_{\mathrm{I}}$ & - & $\mathrm{Y}_{2}$ \\
\hline
\end{tabular}

Keterangan:

$\mathrm{Y}_{\mathrm{I}}$ : Pre-test digunakan untuk menguji pengetahuan awal

$\mathrm{Y}_{2}$ : Post-test digunakan untuk menguji pengetahuan akhir

$\mathrm{X}_{\mathrm{I}}$ : Strategi Socio-scientific Issues based Learning

- : Strategi konvensional

Populasi penelitian ini yaitu seluruh siswa kelas $\mathrm{X}$ SMA Negeri II Yogyakarta dengan menggunakan dua kelas sampel yang menentuan kelasnya menggunakan teknik purposive sampling. Teknik ini merupakan teknik yang didasarkan pada nilai rata-rata kelas pada pelajaran biologi yang cenderung sama pada rapor semester sebelumnya. Kelas sampel dibagi menjadi kelas kontrol dengan pembelajaran konvensional dan kelas eksperimen yang menerapkan pembelajaran Socio-scientific Issues pada materi yang sama. Teknik pengumpulan data menggunakan teknik tes dan non-tes. Teknik tes berupa lembar pre-test- post-test yang berbentuk soal uraian. Soal ini diberikan sebelum dan setelah proses pembelajaran pada kedua kelas sampel. Hal ini untuk mengetahui pengetahuan awal dan pengetahuan akhir 
siswa setelah proses pembelajaran dengan strategi konvensional dan strategi Socio-scientific Issues. Teknik non-tes berupa lembar observasi keterlaksanaan sintaks pembelajaran yang diisi oleh observer.

Validasi instrumen penelitian ini meliputi validasi isi dan konstruk oleh dosen ahli serta validasi empiris yang diperoleh dari hasil ujicoba instrumen pada 34 siswa yang telah menempuh materi tersebut. Reliabilitas instrumen soal yang digunakan telah diuji dengan rumus rumus alpha cronbach dengan hasil reliabilitas sebesar 0.706 yang termasuk kategori reliabel. Analisis data yang dilakukan meliputi uji prasyarat yang terdiri dari normalitas, homogenitas dan uji hipotesis dengan menggunakan uji Wilcoxon.

\section{Hasil dan Pembahasan}

Proses pembelajaran yang berlangsung pada kedua kelas menunjukkan keterlaksanaan sintaks model yang diterapkan berlaku sesuai dengan rencana pembelajaran. Pada kelas eksperimen yang menerapkan model Socioscientific Issues based Learning memiliki karakteristik khas pada proses pembelajaran yang berlangsung. Pada model ini, diterapkan metode role playing yang diperankan siswa dalam mengumpulkan informasi yng berbeda antara satu kelompok dengan kelompok lainnya. Kegiatan ini mendukung peningkatan reflective judgment siswa, sesuai dengan yang diungkapkan Husein Achmad (Hidayati, 2004: 93) bahwa role playing merupakan bentuk permainan pendidikan yang dipakai untuk menjelaskan peranan, sikap, tingkah laku, dan nilai dengan tujuan menghayati perasaan, sudut pandang, dan cara berpikir orang lain. Kegiatan tersebut menanamkan kemampuan bertanggung jawab dan bekerja sama dengan orang lain, menghargai pendapat orang lain dan mengambil keputusan dalam kerja kelompok sehingga dengan kegiatan ini, siswa dilatih untuk mempertimbangkan keputusan dan memutuskan suatu sikap dalam menghadapi suatu isu atau fenomena yang sedang dihadapi. Kegiatan ini melibatkan tiga aspek kognitif yang berkembang dalam situasi sosial, yaitu aspek kognitif meliputi pemecahan masalah, aspek afektif meliputi sikap, dan psikomotor yaitu saat siswa melakukan role playing. Pada kelas kontrol hanya menerapkan model pembelajaran konvensional dimana guru menerangkan dan tanya-jawab dengan siswa. Pembelajaran yang berlangsung cenderung membat siswa menjadi pembelajar pasif dan hanya menerima informasi yang diberikan oleh guru, sehingga kemampuan siswa dalam mengelola informasi, mempertimbangkan suatu keputusan dan berkomunikasi dengan teman kurang terlatih dengan baik.

Kemampuan reflective judgment awal yang dimiliki siswa diketahui dari hasil pengukuran dengan soal pretest menunjukkan bahwa kedua kelas sampel berada pada level pre-reflective. Perbedaan tampak setelah diberikan perlakuan baik pada kelas sampel maupun kelas eksperimen mengalami peningkatan level reflective judgment. Hasil uji hipotesis menggunakan uji Wilcoxon diketahui bahwa pada kelas kontrol menunjukkan pvalue sebesar 0.429 yang artinya tidak terdapat perbedaan level reflective judgment yang signifikan antara sebelum dan sesudah pembelajaran. Berbeda dengan kelas eksperimen, diketahui hasil uji p-value sebesar 0.000 yang artinya terdapat perbedaan kemampuan reflective judgment yang signifikan antara sebelum dan sesudah pembelajaran. Dari hasil uji tersebut diketahui peningkatan kemampuan reflective judgment yang signifikan terjadi pada kelas eksperimen yaitu pada kelas dengan penerapan model Socio-scientific Issues based Learning. Pada awal pembelajaran, di kelas kontrol dan eksperimen masih terdapat siswa yang belum tampak memiliki kemampuan reflective judgment secara berturut-turut sebesar $3.45 \%$ dan II.54\%, namun pada akhir pembelajaran diketahui berdasarkan hasil post-test kedua kelas diketahui seluruh siswa tersebar pada level pre-reflective, quasi reflective dan reflective. Peningkatan tertinggi terjadi pada kelas eksperimen dimana pada awal pembelajaran diketahui level reflective judgment siswa pada kategori reflective hanya sebesar $3.85 \%$ siswa dari anggota kelas namun setelah penerapan model pembelajaran Socio-scientific Issues based Learning diketahui siswa yang berada pada kategori tersebut sebanyak $42.30 \%$. Selengkapnya data persebaran setiap kategori sebagai berikut.

Tabel I. Data Persentase Sebaran Tiap Kategori Reflective Judgment Siswa pada Pre-test dan Post-test

\begin{tabular}{|c|c|c|c|c|c|c|c|c|}
\hline \multirow{3}{*}{ 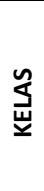 } & \multicolumn{8}{|c|}{ Sebaran Kemampuan Reflective Judgment tiap kategori (\%) } \\
\hline & \multicolumn{2}{|c|}{$\begin{array}{c}\text { TIDAK } \\
\text { MUNCUL }\end{array}$} & \multicolumn{2}{|c|}{ PRE REFLEKTIF } & \multicolumn{2}{|c|}{$\begin{array}{c}\text { KUASI } \\
\text { REFLEKTIF }\end{array}$} & \multicolumn{2}{|c|}{ REFLEKTIF } \\
\hline & $\frac{1}{2}$ & 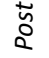 & $\stackrel{2}{2}$ & సัญ & $\stackrel{2}{2}$ & तั & 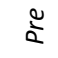 & ֻัญ \\
\hline 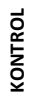 & 3.45 & 0 & 58.62 & 51.72 & 31.03 & 34.48 & 6.89 & 13.79 \\
\hline 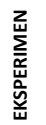 & 11.54 & 0 & 76.92 & 23.07 & 7.69 & 34.62 & 3.85 & 42.30 \\
\hline
\end{tabular}

Persebaran siswa dengan kemampuan reflective judgment yang belum optimal atau masih adanya siswa pada kategori pre-reflective dan quasi reflective menurut Zeidler et.al. (2009: 78), menunjukkan keterbatasan kemampuan reflective judgment siswa yang tidak berkembang optimal selama pembelajaran. Individu prereflective tidak mampu menguji bukti-bukti atau faktafakta kontradiktif yang memungkinkan untuk mengubah kebenaran tunggal yang mereka ketahui, sedangkan individu yang tergolong quasi reflective tidak memiliki pemikiran kritis yang dibutuhkan untuk mengelaborasi bukti-bukti sebagai dasar pengetahuan dan keputusan.

Berikut merupakan contoh ungkapan siswa yang menunjukkan kemampuan reflective judgment pada setiap tahap: 
Tabel 2. Contoh Ungkapan Siswa pada setiap Tahap Kemampuan Reflective Judgment

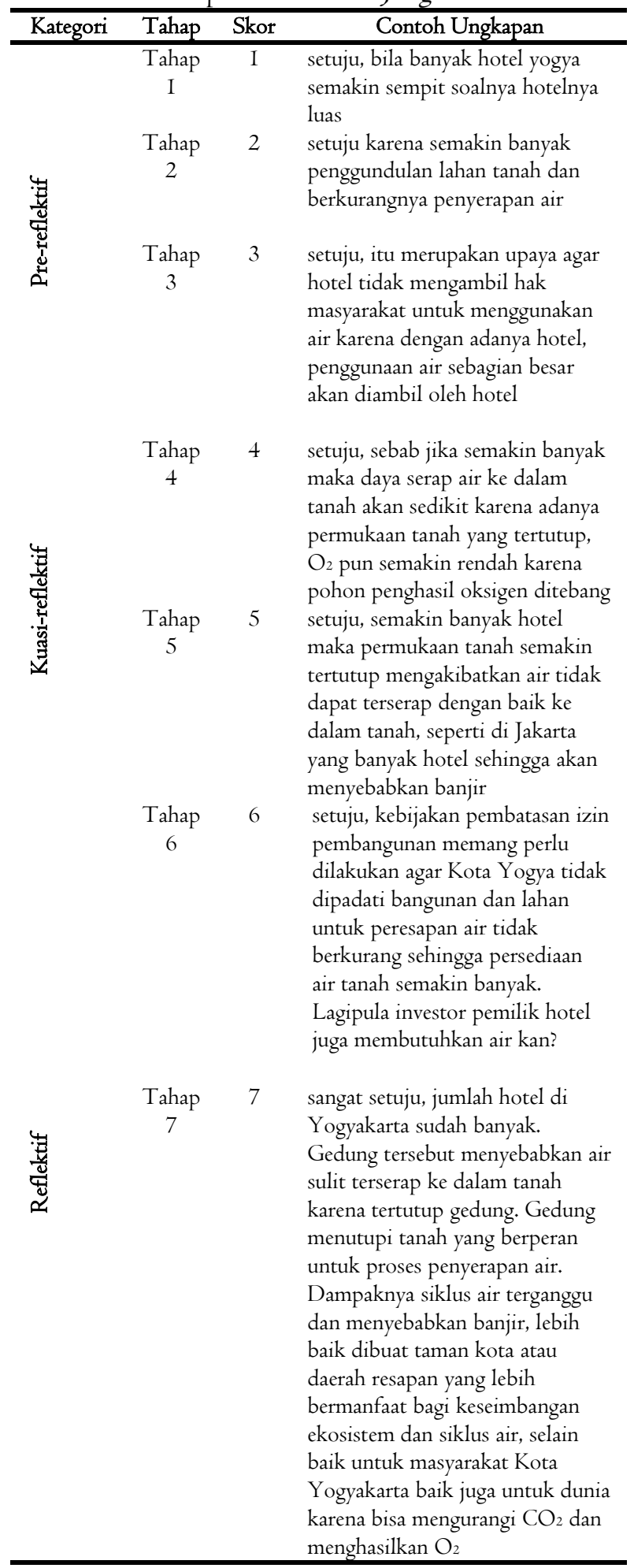

Bila mencermati contoh ungkapan reflective judgment tampak perbedaan pola pikir siswa yang diwujudkan dalam uraian argumen keputusan reflektif siswa saat menanggapi soal terkait isu sosiosains. Kelas eksperimen memperlihatkan kecenderungan perubahan kemampuan reflective judgment yang lebih tinggi bila dibandingkan kelas kontrol. Hal tersebut diketahui dari kecenderungan kategori reflektif siswa yang rendah pada pre-test namun pada post-test mengalami kenaikan sampai pada kategori tertinggi yaitu kategori reflektif. Hal ini menunjukkan kemampuan berargumen siswa meningkat dalam menanggapi isu sosiosains yang diberikan oleh guru. Berdasarkan pengamatan proses pembelajaran pada kelas eksperimen, terdapat banyak peluang bagi siswa untuk melatih kemampuan berpikir kritis yaitu melalui LKS yang diberikan, aktivitas diskusi kelompok, dan aktivitas role playing.

Keterampilan berargumen siswa dalam mengungkapkan pendapat, informasi maupun keputusannya terhadap isu sosiosains berkaitan erat dengan proses perolehan pengetahuan dan pemahaman siswa yang melibatkan keterampilan berpikir tingkat tinggi (higher order thinking skills), khususnya berpikir kritis reflektif. Perubahan pemahaman konsep dan kemampuan reflective judgment siswa, sesuai dengan Zeidler (2009: 74), Socio-scientific Issues menyediakan situasi belajar kontekstual yang berpeluang bagi pengembangan keterampilan ilmiah argumentatif, eksplorasi isu-isu moral, pengembangan penalaran moral dan kemampuan reflective judgment.

Peningkatan tahap reflective judgment siswa didukung dari kegiatan bermain peran yang menuntut siswa aktif untuk berargumen. Sebagaimana yang dijelaskan oleh Topcu, et al., (2010: 2478), strategi Socio-scientific Issues memberi peluang siswa untuk aktif dalam berargumen dan mengumpulkan informasi berbasis data yang didapatkan sehingga akan memunculkan solusi jawaban maupun tanggapan siswa atas suatu persoalan yang bersifat relatif.

Kecenderungan tanggapan siswa dalam berargumen didasarkan pada penyusunan pemahaman siswa, pengalaman belajar dan berdiskusi. Sesuai dengan Felder \& Brent (Zeidler, 2009: 80), kegitan kelompok sangat penting guna mengembangkan kecakapan pribadi siswa dan mendukung pencapaian hasil belajarnya. Dalam kegiatan diskusi kelompok dan role playing (bermain peran), siswa dilatih untuk mempelajari berbagai sudut pandang dalam menghadapi suatu fenomena atau isu, menghargai pendapat orang lain, memempertimbangkan argumen, kritis menanggapi argumen dan data teman, aktif dalam menyampaikan pendapat dan siswa dapat membandingkan pemahaman awal yang dimiliki dengan pemahaman orang lain sehingga akan memudahkan siswa menimbang keputusan dalam menanggapi suatu permasalahan. Selain itu, siswa akan menemukan informasi baru selama role playing berlangsung. Hal ini mendorong perubahan refleksi siswa terkait argumen atau keputusan yang dipilih pada awal pembelajaran dan akhir pembelajaran. Perkembangan intelektual siswa juga akan mengalami perkembangan dalam menghadapi dan menanggapi suatu isu dari berbagai sudut pandang sesuai dengan pemahaman konsep yang telah disusun sendiri oleh siswa.

Pada kelas kontrol, kemampuan reflective judgment kurang berkembang secara optimal pada diri setiap siswa mengingat aktivitas belajar yang dilakukan siswa terbatas pada diskusi dan presentasi hasil diskusi. Diskusi yang 
dilakukan kelas kontrol membahas mengenai kekeringan atau permasalahan sumberdaya air. Permasalahan yang didiskusikan membahas mengenai penangganan dan cara pelestarian sumberdaya air. Selain itu, pada kegiatan presentasi kelas kontrol cenderung pasif karena kurangnya umpan balik dari siswa terhadap presenter yang mempresentasikan hasil diskusinya. Hal tersebut mungkin dikarenakan permasalahan yang dihadapi setiap kelompok sama sehingga jawaban penyelesaian maupun tanggapan siswa terhadap suatu masalah cenderung tidak berbeda jauh.

\section{Simpulan}

Terdapat pengaruh positif pembelajaran Socioscientific Issues terhadap kemampuan reflective judgment pada materi siklus hidrologi. Siswa yang belajar menggunakan Strategi Socio-scientific Issues based Learning memiliki kemampuan reflective judgment yang lebih tinggi pada isu sosiosains materi siklus hidrologi.

\section{Daftar Pustaka}

Anderson, L. A dan Krathwohl, D. R. 2010. Kerangka Landasan untuk Pembelajaran, Pengajaran, dan Asesmen: Revisi Taksonomi Pendidikan Bloom. Terjemahan oleh Agung Prihantoro. Yogyakarta: Pustaka Belajar.

Callahan, Brendan E. 2009. Enhancing Nature of Science Understanding, Reflective Judgment, and Argumentation through Socio-scientific Issues. Dissertation. Florida: University of South Florida.

Cottrell, Stella. 2005. Critical Thinking Skills Developing Effective Analysis and Argument. New York: Palcrave Macmillan.

Hidayati. (2004). Pendidikan Ilmu Pengatahuan Sosial di Sekolah Dasar. Yogyakarta: UNY.

National Science Teachers Association. 2006. Framework for $2 I^{s t} \quad$ Century Learning. http://science.nsta.org/ps/Final2IstCSkillsMapScience. pdf

Nuangchalerm, Prasart \& B. Kwuanthong. 20I0. Teaching "Global Warming" through Socio-scientific Issues-based Instruction. Journal of Asian Social Science. Vol 6 (8): 42-47.

Peraturan Menteri Pendidikan Nasional. 2006. Kurikulum Tingkat Satuan Pendidikan Mata Pelajaran Biologi untuk Sekolah Menengah Atas. Jakarta: Kementerian Pendidikan Nasional.

Sadler, Troy D. (2006). Moral Sensitivity and Its Contribution to the Revolution of Socio-scientific Issues. Journal of Moral Education. Vol 33 (3). Hlm. 339-358.

Saunders, K.J \& Rennie, L.J. 2013. A pedagogical model for ethical inquiry into socioscientific issues in science. Research in Science Education. Vol 43. Hlm. 253-274.

Simonneaux, Jean \& L. Simonneaux. 2012. Educational Configurations for Teaching Environmental Socioscientific Issues Within The Perspective of
Sustainability. Journal of Research in Science Education. Vol 42 (I). Hlm 75-94.

Subiantoro, A.W. Ariyanti, N.A., dan Sulistyo. 2013. Pembelajaran Materi Ekosistem dengan Socio-scientific Issues dan Pengaruhnya Terhadap Reflective Judgment Siswa. Journal Pendidikan IPA Indonesia. Vol 2(I). Hlm. 4I-47.

Topcu, M.S., Sadler T.D. dan Tuzun O.Y. 20IO. Preservice Science Teachers' Informal Reasoning about Socioscientific Issues: The Influence of Issues Context. International Journal of Science Education. Vol 32 (I8). Hlm. 2475-2495.

Zeidler, D.L, Sadler, T.D., Applebaum S., dan Callahan, B.E. 2009. Advancing Reflective Judgment through Socioscientific Issues. Journal of Research in Science Education. Vol 46 (I). Hlm. 74-IOI.

Zeidler, D.L., Sadler T.D., Simmons M.L., dan Howes E.V. 2005. Beyond STS: A Research-Based Framework for Socioscientific Issues Education. Journal of Science Education. Vol 89 (3). Hlm. 357-377. 